\title{
Youtube ve Astım: Astımla İlgili Popüler Videoların Bilgi İçeriğinin Eleştirel Bir Değerlendirmesi
}

\section{Youtube and Asthma: A Critical Review of the Content of Popular Asthma Videos}

\author{
${ }^{1}$ Fatma Esra GÜNAYDIN, ${ }^{2}$ Sedat ALTIN
}

${ }^{1}$ Uludağ Üniversitesi, Göğüs Hastalıkları Ana Bilim Dalı, İmmünoloji ve Alerjik Hastalıklar Bilim Dalı, Bursa, Türkiye ${ }^{2}$ Sağlık Bilimleri Üniversitesi, Yedikule Gögüs Hastalıkları ve Göğüs Cerrahisi Eğitim ve Araştırma Hastanesi, Göğüs Hastalıkları, İstanbul, Türkiye

Fatma Esra Günaydın: https://orcid.org/0000-0002-9268-1071

Sedat Altın: https://orcid.org/0000-0001-7521-8651

\section{ÖZ}

Amaç: Astım dünya genelinde 300 milyondan fazla kişiyi etkilemektedir, astımlı hastalar sıklıkla interneti bir bilgi kaynağı olarak kullanırlar. Youtube ülkemizde internet kullanıcılarının \%92 oranla en sik ziyaret ettiği platformların başında gelmektedir. Bu çalışmanın amacı astımla ilişkili videoların bilgi içeriklerini analiz ederek videoların eğitim kalitesi değerlendirmektir.

Materyal ve Metot: "Astım" anahtar kelimesini kullanarak Youtube araması yapıldı, en çok izlenen 100 video dahil edildi. Özellikler, kaynak ve içerik açısından analiz edildi. Video kalitesini değerlendirmek için bir puanlama sistemi oluşturuldu.

Bulgular: Yüz video analiz edildi, konu içeriği olarak en sık hasta eğitimi ile ilgili (\%58), ikinci sırada alternatif tedavilerle ilgili videolar yer almaktaydı (\%37). Diğer sağlık profesyonellerinin videoları en yüksek puana sahipti ve diğer kaynaklardan önemli ölçüde yüksekti. Alternatif tıp kanallarını izlenme sayısı sağlık profesyonellerinin izlenme sayısından yüksekti.

Sonuç: YouTube platformundaki en çok izlenen astım videoları değerlendirildi, içerik analizi yapıldığında sağlık profesyonellerinin videoları en yüksek kalitedeydi, ancak izlenme oranlarına göre bakıldığında en çok alternatif tıp içerikli videoların izlendiği görüldü. Astımla ilgilenen sağlık profesyonelleri tarafindan üretilecek daha çok izlenecek yüksek kaliteli, eğitici materyaller üretilmesine ihtiyaç vardır.

Anahtar Kelimeler: Alternatif tıp, astım, internet

\begin{abstract}
Objective: Asthma affects more than 300 million people worldwide, patients with asthma often use the Internet as a source of information. Youtube is the world's largest and most visited video site, with $92 \%$ of internet users in our country visiting it. The aim of this study is to evaluate the quality of education by analyzing the information content of asthma-related videos on the most commonly used platform.
\end{abstract}

Materials and Methods: YouTube search was performed using the keyword "astım", including the 100 most Turkish Asthma videos were analyzed for characteristics, source, and content. A scoring system was established to assess quality of video.

Results: One hundred videos were analyzed, subject content was most commonly related to patient education $(58 \%)$, while the second included videos about alternative treatments $(37 \%)$. Videos of other health professionals had the highest score. View number of alternative medicine channels was higher than health professionals.

Conclusion: The most watched asthma videos on YouTube platform were evaluated, the videos of health professionals had highest quality, but the videos with the most alternative medicine content were viewed according to their viewing rates. There is a need to produce highquality, educational materials by asthma healthcare professionals.

Keywords: Alternative medicine, asthma, internet

Yayın Bilgisi / Article Info:

Gönderi Tarihi/ Received: 11/07/2020

Kabul Tarihi/ Accepted: 27/09/2020

Online Yayın Tarihi/ Published: 30/12/2020 


\section{GİRIŞ}

Astım tüm yaş gruplarında görülebilen, dünyada 300 milyondan fazla kişiyi, ülkemizde yaklaşık 3.5 milyon kişiyi etkileyen önemli bir sağlık problemidir. ${ }^{1}$ Ülkemizde doktor tanılı astım sıklığı erkeklerde \% 2,8, kadınlarda \%6,2'dir. ${ }^{2}$ Astımlı hastalarda bilgi kaynağı olarak internet kullanımı \%65 olarak gösterilmiştir. ${ }^{3}$ Youtube $^{4}$ en popüler üçüncü web sitesi olup, bir milyar kullanıcıya sahip, kullanıcıların video yükleyip, paylaşabildiği, yorum yapabildiği medya paylaşım sitesidir. ${ }^{5}$ Daha önceki çalışmalarda gastroözefagial reflü, sistemik lupus eritematozus, benign prostat hiperplazisi, Çölyak hastalığı, Human Papilloma virüsü aşısı, eklem hastalıkları, adenotonsillektomi gibi pek çok tıbbi başlık hakkında olan videoların tıbbi bilgi içerikleri değerlendirilmişti. ${ }^{6-12}$ Astımla ilgili çok sayıda video olup, hastalar tarafından bilgi kaynağı olarak kullanılmaktadır ancak literatürde bu videoların içeriklerinin sağlık profesyonelleri tarafından değerlendirildiği sadece bir çalışma mevcuttur. ${ }^{3}$ Çalışmamızda ülkemizde de sıklıkla bilgi kaynağı olarak kullanılan Youtube platformunda astımla ilgili Türkçe videoların tıbbi içeriklerini analiz ederek videoların eğitim kalitesini değerlendirmek amaçlanmıştır, bu konuda ülkemizde yapılan ilk çalışma olma özelliğini taşımaktadır.

\section{MATERYAL VE METOT}

Çalışmaya 18 Temmuz-6 Ağustos 2019 tarihleri arasında YouTube da paylaşılmış ve içerisinde "astım" anahtar kelimesi geçen videolar belirlendi. Türkçe dilinde, iyi görsel kaliteye sahip (240 piksel üzeri çözünürlüğe sahip), 20 dakikadan kısa süreli videolar dahil edildi. 2000 görüntülemenin altındaki videolar değerlendirmeye alınmadı. Düşük çözünürlük kalitesine sahip videolar dışlandı. En çok izlenen 100 video çalışmaya dahil edildi. Astım videoları özellikler, kaynak ve içerik açısından analiz edildi. Video süresi, konuşmacının cinsiyeti, görüntüleme sayıs1, beğenme ve beğenmeme sayıs1, yorum sayıs1 analiz edildi. Araştırmanın verileri toplanmadan önce Sağlık Bilimleri Üniversitesi İstanbul Eğitim ve Araştırma Hastanesi Klinik Araştırmalar Etik Kurulundan onay alındı (Tarih: 12/06/2020, karar no: 2414).

Video kaynakları beş gruba ayrıldı; astımla ilgili sağlık profesyonelleri (erişkin ve çocuk göğüs hastalıkları uzmanları), diğer sağlık profesyonelleri (acil tıp uzmanları, paramedikler, kurumsallaşmış hastaneler...), ilaç firmaları, alternatif tıp ile uğraşan kurum ve kişiler, televizyon medya kanalları olarak sınıflandırıldı. Astımla ilgili YouTube videolarının kalitesini değerlendirmek için bir puanlama sistemi oluşturuldu (Tablo 1) $(-3$ ile +26 puan arasında). Puanlama sistemi oluşturulurken Gonzalez- Estrada ve arkadaşlarının geliştirdiği puanlama sistemi kullanıldı. Hastalar için “Astımlı hastaların \%99'u alerjik bünyeye sahiptir", "Kortizon hastalığı kötüleştirir" gibi her yanlış bilgi için -1 puan verildi, toplam skor hesaplandi.

Istatiksel Analiz: Verilerin istatistiksel analizleri için IBM SPSS Statistics 23 (Chicago, Illinois, USA) paket programı kullandı. Tanımlayıcı istatistiksel metotların (ortalama, standart sapma) yanı sıra, ikili grupların karşılaştırmasında bağımsız t testi, verilerin karşılaştırmalarında ki-kare testi, normal dağllım göstermeyen parametrelerin gruplar arası karşılaştırmalarında Kruskal-Wallis testi kullanılmıştır. Çalışmada, anlamlılık düzeyi $\mathrm{p}<0,05$ olarak alınmıştır.

\section{BULGULAR}

"Astım" anahtar kelimesi ilişkili 281 video saptandı, izlenme sayılarına göre sıralandığında ilk 100 video analiz edildi. Videoların genel özellikleri tablo 1 de özetlenmiştir. Ortalama görüntüleme sayısı 48.258, ortalama video süresi $152 \mathrm{sn}, 271$ beğeni ve 21 beğenmeme mevcuttu. Video sunucusu sıklıkla erkekti (\%59) (Tablo 2).

En yaygın video kaynağı astımla ilgili sağlık profesyonelleriydi (\%41). İkinci sirada televizyon medya kanalları (\%23), üçüncü olarak alternatif tıp ile uğraşan kurum ve kişiler (\%22) gelmekteydi (Șekil 1). Konu içeriği olarak en sık hasta eğitimi ile ilgili (\% 58), ikinci sırada alternatif tedavilerle ilgili videolar yer almaktaydı (\%37) (Sekil 2). Alternatif tedaviler; kekik, keçi boynuzu, siyah turp, ozon yağı, eşek sütü, yeşil yulaf samanı, zencefil tüketimi egzersizler, hacamat uygulaması ile ilgiliydi.

Video içeriği analizi açısından değerlendirildiğinde; diğer sağlık profesyonelleri en yüksek puana sahipti, astımla ilgili sağlık profesyonelleri, ilaç firmaları, alternatif tıpla uğraşan kurum ve kişiler ve televizyon medya kanalları takip etti (Tablo 3). Alternatif tıp kanallarını izlenme sayısı en yüksekti $(97,186)$, sağlık profesyonellerinin görüntüleme sayısı 23,107 idi, fark istatiksel olarak anlamlıydı $(\mathrm{p}<0.05)$.

\section{TARTIŞMA VE SONUÇ}

Günümüzde internet sağlık bilgisi içeren en büyük ve güncel kaynak hâline gelmiştir. YouTube dünya genelinde en çok erişilen üçüncü internet sitesi ol- 
ması nedeniyle kısa sürede çok sayıda kişiye mesaj ulaştırabilmektedir. ${ }^{3-5}$ Hastalıklarla ilgili bilgi kaynağ olarak da kullanılan videolarda iletilen mesajların içeriklerini analiz eden çalışmalar bulunmaktadır ve sayıları artmaktadır. YouTube'daki astımla ilgili videolarının içeriğini değerlendiren araştırma sayısı azdır, Türkçe dilinde rastlanmamıştır. Bu eksikliği gidermek amacıyla yaptığımız araştırma kapsamında incelenen videoların içeriği, video özellikleri, kaynakları analiz edilmiştir.

Sağlıkla ilgili bilgi kaynağı olarak sıklıkla kullanılan Youtube platformunda astımla ilgili en çok izlenen 100 video analiz edildi. Çalışmamız genel olarak astımla ilgili videoların bilgi kaynağı olarak zayıf olduğunu gösterdi. Literatürde çeşitli tıbbi konularla ilgili videoların içeriklerinin incelendiği çalışmalarda yüksek kalitede videonun az olduğu belirtilmiştir. ${ }^{5-12}$ En sık hasta eğitimi içerikli videoların olduğu görüldü (\%58). Video puanlarına bakıldığında astımla ilgili ve diğer sağlık profesyonellerinin videolarının puanlarının diğer kaynaklara göre anlamlı yüksek olduğu gösterildi. Gonzalez-Estrada ve arkadaşları İngilizce dilinde en sık izlenen 200 astımla ilgili videoyu inceledikleri çalışmalarında en sık alternatif tıpla ilgili videoların olduğunu göstermişler ve sağlık profesyonellerinin videolarının puanlarının diğer kaynaklara göre yüksek olduğunu göstermişler. ${ }^{3}$

İzlenme sayılarına göre videolar değerlendirildiğinde alternatif tıpla ilgilenen kişi ve/ veya kurumların izlenme sayısının diğer kaynaklara göre yüksek olduğu dikkat çekmektedir, bu durum alternatif tıbba olan ilgiyi göstermektedir. Alternatif tedaviler; kekik, keçi boynuzu, siyah turp, ozon yağı, eşek sütü, yeşil yulaf samanı, zencefil tüketimi egzersizler, hacamat uygulaması ile ilgiliydi. Astımla ilgili videoları analiz eden Gonzalez-Estrada ve arkadaşları, aşılamayla ilgili videoları inceleyen Keelan ve arkadaşları çalışmalarında alternatif tıpla ilgili videoların daha fazla izlendiğini göstermişler. ${ }^{3,13}$ Alternatif tıpla ilgili videoların puan ortalaması sağlık profesyonellerinin ve ilaç firmalarının astımla ilgili videolarından düşüktü. Astımla ilgilenen sağlık profesyonelleri alternatif tedavilerin farkında olmalı ve hastalarıyla kapsamlı bir şekilde hastaları bilgilendirebilmelidir.

Çalışmamızda astımla ilgili sağlık profesyonellerinin videolarının en az izlenen video grubu olması dikkat çekicidir. Benzer olarak Desai ve arkadaşları toplumun yüksek kalitede, sağlık bakımı sağlayıcılarının videolarını az izlediklerini ifade etmişler. ${ }^{14}$ Asıl soru, bu tür videoların çekiciliğinin nasıl geliştirilece- ğidir. Bu tür videoların çekiciliğini arttırma stratejileri YouTube'da popüler olan astım videolarında sunan kişinin ünlü veya sporcu olması, video içeriğinde kısa ve eğlenceli bir bilgi içermesi olabilir. ${ }^{15}$

Çalışmamızın çeşitli kısıtlılıkları vardı, "astım" ile ilişkili 281 videodan en çok görüntüleme sayısına sahip 100 video izlendi, diğer videolar incelenemedi. Türkçe dili dışındaki videolar incelenmedi.

Sonuç olarak, astımla ilgili YouTube videoları sıklıkla görüntülenmektedir ancak kanıta dayalı bilgi açısından zayıf bir kaynaktır. Çalışmamızda astımla ilişkili en çok izlenen 100 video değerlendirildi, en çok astımla ilgilenen sağlık profesyonellerinin videoları mevcuttu ve en sık içerik hasta eğitimi ile ilgiliydi. Video bilgi içeriği olarak değerlendirme yapıldığında sağlık profesyonellerinin daha yüksek bilgiye sahip ancak daha az izlenen videoları olduğu görüldü. Bilgi içeriği yüksek sağlık profesyonelleri videolarının daha çok izlenmesinin sağlanması, diğer kaynakların bilgi içeriğinin zenginleştirilmesi hasta bilgilendirmesinde önemli rol oynayabilir, bu konuda sosyal medya çalışması yapılabilir.

Etik Komite Onayt: Çalışma için Sağlık Bilimleri Üniversitesi İstanbul Eğitim ve Araştırma Hastanesi Klinik Araştırmalar Etik Kurulu'ndan etik onayı alındı (Tarih: 12/06/2020, karar no: 2414).

Çıkar Çatışması: Yazarlar çıkar çatışması bildirmemişlerdir.

Yazar Katkılart: Fikir - FEG; Denetleme - SA; Veri toplanması ve işlemesi - FEG; Analiz ve yorum FEG, SA; Yazıyı yazan -FEG, SA

Hakem değerlendirmesi: Dış bağımsız

\section{KAYNAKLAR}

1. Türk Toraks Derneği (TTD). Astım tanı ve tedavi rehberi. 2016. Turk Thoracic J. 2016;17(1):1108.

2. Global initiative for asthma (GINA). Global strategy for asthma management and prevention, 2020. https://ginasthma.org/wp-content/ uploads/2020/06/GINA-2020-report_20_06_04-1 -wms.pdf. Erişim tarihi 21 Haziran 2020.

3. Gonzalez-Estrada A, Cuervo-Pardo L, Ghosh B, ve ark. Popular on YouTube: A critical appraisal of the educational quality of information regarding asthma. Allergy Asthma Proc. 2015;36 (6):121-126. doi:10.2500/aap.2015.36.3890

4. YouTube. http://www.youtube.com. Erişim tarihi 20-30 Haziran 2020.

5. YouTube by the numbers: stats, demographics \& fun facts 2020 . https:// 
www.omnicoreagency.com/youtube-statistics/.

Erişim tarihi 20 Haziran 2020.

6. Aydin MF, Aydin MA. Quality and reliability of information available on YouTube and Google pertaining gastroesophageal reflux disease. Int $\mathrm{J}$ Med Inform. 2020;137:104-107. doi:10.1016/ j.ijmedinf.2020.104107

7. Ng CH, Lim GRS, Fong W. Quality of Englishlanguage videos on YouTube as a source of information on systemic lupus erythematosus. Int $\mathrm{J}$ Rheum Dis. 2020;00:1-9. doi:10.1111/1756185X.13852

8. Betschart P, Manolis Pratsinis M, Müllhaupt G, ve ark. Information on surgical treatment of benign prostatic hyperplasia on YouTube is highly biased and misleading. BJU Int. 2020;125(4):595 -601. doi:10.1111/bju.14971

9. Basch CH, Hillyer GC, Garcia P, Basch CE. Content of widely viewed youtube videos about celiac disease. Public Health. 2019;167:147-151. doi:10.1016/j.puhe.2018.11.004

10. Kuru T, Erken HY. Evaluation of the quality and reliability of YouTube videos on rotator cuff tears. Cureus. 2020;3;12(2):6852. doi: 10.7759/ cureus. 6852

11. Ekram S, Debiec KE, Pumper MA, Moreno MA. Content and commentary: HPV vaccine and YouTube. J Pediatr Adolesc Gynecol. 2019;32 (2):153-157. doi:10.1016/j.jpag.2018.11.001

12. Ward B, Bavier R, Warren C, Yan J, Paskhover B. Qualitative evaluation of paediatric surgical otolaryngology content on YouTube. J Laryngol Otol. 2020;13:1-3. doi:10.1017/ S002221512000016X

13. Keelan J, Pavri-Garcia V, Tomlinson G, ve ark. Youtube as a source of information on imunization: A content analysis. JAMA. 2017;298:24822484. doi:10.1001/jama.298.21.2482

14. Desai T, Shariff A, Dhingra V, ve ark. Is content really king? An objective analysis of the public's response to medical videos on YouTube. PLoS One. 2013;8(12):82469. doi: 10.1371/ journal.pone. 0082469

15. Qualities than can make your video go viral. http://blog.hubspot.com/blog/tabid/6307/ bid/4915/10-Qualities-That-Can-Make-YourVideo-Go-Viral.aspx. Erişim tarihi 22 Haziran 2020. 
Tablo 1. Astımla ilgili sağlık bilgilerini değer lendir mek için puan sistemi.

\begin{tabular}{|c|c|}
\hline Etyolojiden bahsetme (bilinmeyen, genetik) & 1 puan \\
\hline Patofizyolojiden bahsetme(bronşiyal astım, mukus prodüksiyonu, bronkokonstrüksiyon) & 1 puan \\
\hline Astımın tetikleyicilerinden bahsetme & 1 puan \\
\hline \multicolumn{2}{|l|}{ Allerjen tetikleyicileri (Herbiri 1 puan, maksimum 5 puan) } \\
\hline Egzersiz & 1 puan \\
\hline ÜSYE & 1 puan \\
\hline Reflü & 1 puan \\
\hline İritan hava kirliliği, sigara & 1 puan \\
\hline Soğuk hava & 1 puan \\
\hline Stres & 1 puan \\
\hline \multicolumn{2}{|l|}{ Semptomlar ( Her biri 1 puan, maksimum 5 puan ) } \\
\hline Göğüste sıkışma & 1 puan \\
\hline Vizing & 1 puan \\
\hline Nefes daralması & 1 puan \\
\hline Öksürük & 1 puan \\
\hline Gece semptomu & 1 puan \\
\hline \multicolumn{2}{|l|}{ Tanı yöntemi ( Her biri 1 puan, maksimum 3 puan ) } \\
\hline Öykü & 1 puan \\
\hline SFT & 1 puan \\
\hline İlaca yanıt & 1 puan \\
\hline Astımın sınıflaması & 1 puan \\
\hline Kaçınma & 1 puan \\
\hline Doğru teknikle ilaç kullanımı & 1 puan \\
\hline İmmünoterapi & 1 puan \\
\hline PEF kullanımı & 1 puan \\
\hline Kontrol edici tedavi edici ilaçları tartışma & 1 puan \\
\hline İlaçlardan bahsetme & 1 puan \\
\hline İlaç yan etkileri hakkında bilgi & 1 puan \\
\hline Yanlış bilgi (her biri için) & -1 puan \\
\hline
\end{tabular}


Tablo 2. Videoların genel özellikleri.

\begin{tabular}{|l|c|}
\hline Değişkenler & n \\
\hline Erkek sunucu & 59 \\
\hline Ortalama görüntüleme sayısı & 48.258 \\
\hline Ortalama beğeni sayısı & 271 \\
\hline Ortalama beğenmeme sayısı & 21 \\
\hline Ortalama süre, sn & 152 \\
\hline
\end{tabular}

Sn: saniye 
Tablo 3. Video kaynaklarının or talama puanları.

\begin{tabular}{|l|c|}
\hline Video kaynağı & Ortalama puan \\
\hline Astımla ilgili sağlık profesyonelleri & 4 \\
\hline Diğer sağlı profesyonelleri* & 7 \\
\hline İlaç firmaları & 6 \\
\hline Alternatif tıpla uğraşan kurum ve kişiler & 1,5 \\
\hline Televizyon medya kanalları & 0,9 \\
\hline
\end{tabular}

* Acil tıp uzmanları, paramedikler, kurumsallaşmış hastaneler 


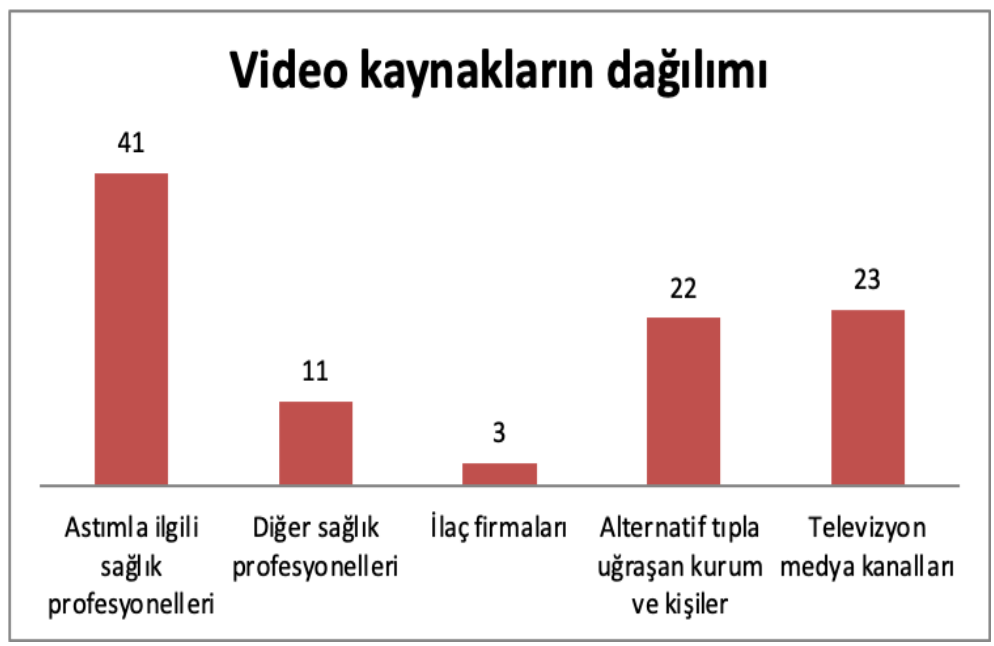

Şekil 1. Video kaynaklarının dağılımı. 


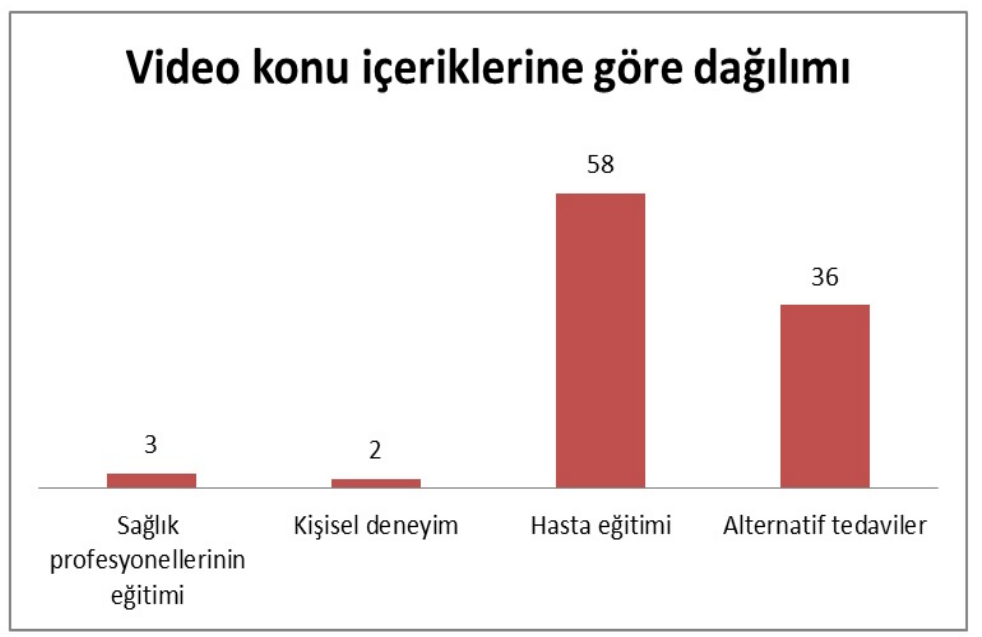

Şekil 2. Video konu içerikler ine göre dağılımı. 